\title{
ŁUKASZ STĘPKOWSKI
}

Uniwersytet Wrocławski

\section{Sprawozdanie z wręczenia nagród w konkursie Sędzia Europejski 2017 oraz z dyskusji panelowej zatytułowanej „Unia Europejska jest unią prawa”, Wrocław, 18 maja 2018 roku}

Osiemnastego maja 2018 roku we Wrocławiu, w Sali Unii Europejskiej na Wydziale Prawa, Administracji i Ekonomii Uniwersytetu Wrocławskiego odbyło się wręczenie nagród przyznawanych corocznie w konkursie Sędzia Europejski. Samo wydarzenie miało charakter otwarty dla publiczności i zostało połączone z dyskusją panelową o charakterze naukowym w przedmiocie „Unia Europejska jest unią prawa”. Organizatorami wydarzenia były Zarząd Główny Polskiej Sekcji Międzynarodowej Komisji Prawników (International Commission of Jurists) oraz Wydział Prawa, Administracji i Ekonomii Uniwersytetu Wrocławskiego.

Przed oficjalnym rozpoczęciem przyjęci zostali przez Dziekana Wydziału Prawa, Administracji i Ekonomii Profesora dr. hab. Karola Kiczkę Profesor dr hab. Zbigniew Lasocik — Prezes Zarządu Polskiej Sekcji Międzynarodowej Komisji Prawników oraz, będący również jej członkiem, Profesor dr hab. Andrzej Rzepliński - Prezes Trybunału Konstytucyjnego w latach 2010-2016, kierownik Katedry Kryminologii i Polityki Kryminalnej Instytutu Profilaktyki Społecznej i Resocjalizacji Wydziału Stosowanych Nauk Społecznych i Resocjalizacji Uniwersytetu Warszawskiego. Ponadto w spotkaniu wzięli udział dr hab. Aleksander Cieśliński z tutejszego Wydziału oraz dr Maciej Taborowski z Wydziału Prawa i Administracji Uniwersytetu Warszawskiego. W trakcie spotkania poruszano kwestie stosowania prawa Unii Europejskiej oraz korzystania z procedury pytań prejudycjalnych w polskich sądach, jak również obecne wyzwania związane z przestrzeganiem zasad praworządności.

W trakcie wręczania nagród Polska Sekcja Międzynarodowej Komisji Prawników była reprezentowana między innymi przez Profesora dr. hab. Zbigniewa Laso- 
cika, Adwokatów: Marka Zielińskiego (Skarbnika) oraz Michała Zuchmantowicza (Sekretarza) przy jednoczesnej obecności członków PSMKP — Profesora dr. hab. Andrzeja Rzeplińskiego, Profesor dr hab. Eleonory Zielińskiej oraz Radczyni Prawnej Doroty Hajduk. Stronę Uniwersytetu reprezentowali Profesor dr hab. Wiesława Miemiec (Prorektor ds. finansów i rozwoju), a także Profesor dr hab. Karol Kiczka przy obecności kadry akademickiej. W dyskusji panelowej czynny udział wzięli Dr hab. Aleksander Cieśliński (UWr), Dr Agnieszka Frąckowiak-Adamska (UWr) oraz Dr Maciej Taborowski (UW). Ponadto w wydarzeniu jako słuchacze wzięli udział sędziowie, członkawie adwokatury oraz samorządu radcowskiego, nauczyciele akademiccy i doktoranci oraz studenci WPAiE UWr. Wypada odnotować, że wydarzenie po raz pierwszy odbywało się we Wrocławiu, dotychczas miało bowiem miejsce w Sądzie Najwyższym lub w Trybunale Konstytucyjnym.

Spotkanie otworzył Profesor Zbigniew Lasocik, dokonując prezentacji osób zebranych oraz przedstawienia działalności PSMKP ${ }^{1}$, po czym wystąpili Profesor Wiesława Miemiec oraz Profesor Karol Kiczka. Odnotowano między innymi, że spotkania takie jak omawiane wydarzenie są, zwłaszcza obecnie, niezwykle konieczne, kiedy trzeba dyskutować, rozmawiać na temat stosowania prawa w szczególności przez tych sędziów, którzy orzekają w sprawach międzynarodowych, a więc z uwzględnieniem różnych elementów zarówno prawa polskiego, jak i prawa europejskiego. Wskazano zaś w szczególności, że przestrzeganie wiążącego prawa międzynarodowego jest nakazem rangi konstytucyjnej, który powinien być zapewniany w rzeczywistości, w drodze bezpośredniego stosowania Konstytucji Rzeczpospolitej Polskiej².

Po przedstawieniu powyższych uwag oraz siedemnastoletniej historii nagrody Sędzia Europejski dokonano prezentacji laureatek i laureatów XVII edycji nagrody Sędzia Europejski za rok 2017, w kolejno prezentowanych kategoriach: Sądy Apelacyjne, Sądy Okręgowe, Sądy Rejonowe, Wojewódzkie Sądy Administracyjne oraz Naczelny Sąd Administracyjny. W kategorii Sądy Apelacyjne uhonorowano SSA Darię Stanek (Sąd Apelacyjny w Gdańsku, III Wydział Pracy i Ubezpieczeń Społecznych). W kategorii Sądy Okręgowe uhonorowano SSO Przemysława Feligę (Sąd Okręgowy w Warszawie, XVI Wydział Gospodarczy, del. do Sądu Apelacyjnego w Warszawie, I Wydział Cywilny). W kategorii Sądy Rejonowe uhonorowano SSR Aleksandrę Rutkowską (Sąd Rejonowy dla Wrocławia - Śródmieścia we Wrocławiu, X Wydział Pracy i Ubezpieczeń Społecznych). W kategorii Wojewódzkie Sądy Administracyjne uhonorowano sędzię WSA Bożenę Blitek (Wojewódzki Sąd Administracyjny w Krakowie). W kategorii NSA uhonorowano SNSA Romana Wiatrowskiego (Naczelny Sąd Administracyjny). Jury przyznało również trzy wyróżnienia: SSO delegowany do SA Krzysztofowi Krukowi (SO w Białymstoku, I Wydział Cywilny, del. do SA w Białymstoku),

\footnotetext{
1 Por. http://www.psmkp.pl/node/8 (dostęp: 24.05.2018).

2 Dz.U. z 1997 r. Nr 78, poz. 483 z późn. zm.
} 
SSR delegowany do SO Zygmuntowi Drożdżejce (delegowany SO w Krakowie, I Wydział Cywilny) oraz SSR Rafałowi Cebuli (SR w Siemianowicach Śląskich). Organizatorzy podkreślili, że nie chodziło o współzawodnictwo w orzekaniu, lecz o rodzaj inspiracji do spojrzenia na niektóre problemy pojawiające się w orzecznictwie sądowym z punktu widzenia zasad, na których opiera się Unia Europejska — zasad pierwszeństwa i bezpośredniego stosowania prawa unijnego. Organizatorzy wskazali, że w tym sensie laureatami konkursu są wszyscy sędziowie, a ujmując szerzej w rzeczywistości, wszyscy uczestnicy procesu jurysdykcyjnego, którzy na jego różnych etapach zadają sobie trud poszukiwania podstaw rozstrzygnięcia sporu sądowego na podstawie norm prawa międzynarodowego albo szczególnie prawa unijnego, oraz nierzadko konfrontują wyniki analizy prawnej opartej na prawie krajowym z normą prawa europejskiego, której polskie prawo konstytucyjne przyznaje pierwszeństwo stosowania w ramach art. 91 ust. 3 KRP. Zaprezentowano również niektóre interesujące elementy nagrodzonego orzecznictwa, między innymi zgłoszone przez nagrodzonych pytania prejudycjalne ${ }^{3}$.

Po prezentacji i laudacji na cześć laureatek i laureatów nastąpiło wręczenie dyplomów honorowych, przyznających tytuł Sędzia Europejski oraz przekazanie symbolicznych granitowych statuetek i nagród książkowych. SSR Aleksandra Rutkowska wygłosiła podziękowanie w imieniu zgromadzonych laureatek i laureatów, wskazując, że korzystanie z dorobku prawa Unii w praktyce orzeczniczej wywołuje wymierną korzyść dla jakości tego orzecznictwa oraz skuteczności orzekania. Zdaniem laureatki dzięki zadaniu pytania prejudycjalnego sędziowie krajowi są w stanie bez wątpliwości rozstrzygać sprawy zwolnień grupowych, a w wyniku wydania wyroku przez TS wiele spraw rozpoznawanych przed sądami krajowymi zostało szybciej zakończonych.

Omawiane wydarzenie następnie przeszło do części panelowej. Moderatorem dyskusji panelowej był Dr hab. Aleksander Cieśliński, który tytułem wstępu wskazał, że biorąc pod uwagę najnowsze orzecznictwo Trybunału Sprawiedliwości Unii Europejskiej, omawiane przez panel zagadnienie ma bardzo praktyczny wymiar zarówno materialny, jak i proceduralny, albowiem tytułem tego ostatniego wszędzie można usłyszeć odniesienia do tak zwanej procedury kontroli praworządności ${ }^{4}$. Sformułowano też pytanie badawcze: co to znaczy, że UE jest unią prawa - czy chodzi jedynie o to, że należy przestrzegać przepisów, ewentualnie biorąc pod uwagę, że system prawa unijnego ma swoją wewnętrzną kontrolę aktów prawnych do jego co do ich zgodności z aktami wyższego rzędu ${ }^{5}$, czy może

3 Por. https://www.saos.org.pl/judgments/317301 (SSR R. Cebula, dostęp: 23.05.2018) oraz https://www.saos.org.pl/judgments/217138 (SSR A. Rutkowska, dostęp: 23.05.2018).

${ }^{4}$ Komunikat Komisji do Parlamentu Europejskiego i Rady - Nowe ramy UE na rzecz umocnienia praworządności, COM/2014/0158 final, http:/eur-lex.europa.eu/legal-content/PL/TXT/?qid= 1527122594234\&uri=CELEX:52014DC0158 (dostęp: 23.05.2018).

5 Por. tytułem takiego podejścia wyrok Trybunału z dnia 3 października 2013 roku, sprawa C-583/11 P Inuit Tapiriit Kanatami i in. przeciwko Parlamentowi Europejskiemu i Radzie Unii Eu- 
ma to głębszą, istotniejszą treść ${ }^{6}$. Odwołano się tutaj do art. 2 TUE na okoliczność tego, że UE nie ma być jedynie unią interesów, a uchybienie wartościom może rodzić bardziej dalekosiężne skutki prawne niż uchybienie konkretnym zobowiązaniom państwa członkowskiego. Zdaniem moderatora art. 2 TUE nie jest obojętny dla TSUE lub sądu krajowego przy orzekaniu, a pojęcie praworządności (czy państwa prawnego, stosowane zamiennie) ma obecnie swoje autonomiczne znaczenie w prawie Unii, jakkolwiek inspirowane tradycjami konstytucyjnymi państw członkowskich. Treść tego pojęcia jest ustalana poprzez wiążące akty normatywne Unii, lecz także akty tak zwanego prawa miękkiego (soft law), między innymi przez dokument Komisji „Nowe ramy praworządności”. Co więcej owa treść i orzecznictwo w jej przedmiocie są inspirowane również przez dorobek Komisji Weneckiej (to jest Europejskiej Komisji na rzecz Demokracji przez Prawo), w szczególności zaś przez checklist owej Komisji, a więc wyjątkowo zewnętrzny dla systemu prawa UE dokument ${ }^{7}$. Dokument ów precyzyjnie analizuje, co należy rozumieć przez niezależność i niezawisłość sędziowską. Natomiast gdy pojawia się stanowisko kontrolowanego państwa, to niejako zaraz pojawia się argument o istnieniu autonomii krajowej, a bardziej zaawansowane państwa powołują się na zasadę pomocniczości. Przede wszystkim ma się do czynienia z powoływaniem się na art. 4 ust. 2 Traktatu o Unii Europejskiej, który mówi o poszanowaniu tożsamości narodowej. Mówiąc konkretnie o tożsamości, okazuje się że tożsamość konstytucyjna może być wykorzystywana w orzecznictwie jako na przykład równowaga do stosowania przepisów prawa unijnego. Mamy bardzo bogate orzecznictwo dotyczące kolizji między swobodami rynku wewnętrznego i prawami obywatelskimi (na przykład swobodą przemieszczania się) a orzecznictwem o ochronie tożsamości konstytucyjnej. Tutaj Trybunał jest bardzo otwarty na argumentację państwa, co widać między innymi w sprawie Malgožata Runevič-Vardyn i Łukasz Paweł Wardyn dotyczącej pisowni polskich nazwisk na Litwie ${ }^{8}$. Granicę indywidualizmu państwa stanowi jednak poszanowanie wartości praworządności. W tym zakresie należy zadać następne pytanie: czy chodzi tylko o aspekty formalne, czy znaczy to, że ma to być państwo prawne w aspekcie materialnym. Osadzenie w art. 2 TUE jest też o tyle istotne, że kiedy mówi się o wartościach unijnych, to praworządność nie może być oderwana od dwóch innych wartości, stanowiąc z nimi jedną całość — z poszanowaniem praw człowieka i demokracją. Nie można przeciwstawiać praworządności demokracji, jak to się ostatnio czyni

ropejskiej, EU:C:2013:625, pkt 91, wyrok Sądu z dnia 20 września 2011 roku, sprawa T-461/08 Evropaïki Dynamiki - Proigmena Systimata Tilepikoinonion Pliroforikis kai Tilematikis AE przeciwko Europejskiemu Bankowi Inwestycyjnemu (BEI), EU:T:2011:494, pkt 46.

${ }^{6}$ Por. tytułem takiego podejścia opinia 2/13, pełny skład TS, EU:C:2014:2454, pkt 168.

7 Por. http://www.venice.coe.int/webforms/documents/?pdf=CDL-AD(2016)007-e (dostęp: 23.05.2018).

8 Wyrok Trybunału z dnia 12 maja 2011 roku, sprawa C-391/09 Malgožata Runevič-Vardyn i Łukasz Pawet Wardyn przeciwko Vilniaus miesto savivaldybès administracija i inni, EU:C:2011:291. 
w polskim kontekście. Nie można także porównywać całego systemu krajowego na podstawie jednego konkretnego rozwiązania - należy zamiast tego pamiętać, że Traktat posługuje się pojęciem stałego i poważnego naruszenia. Należy więc odnosić się nie do jednego rozwiązania, lecz do zdemontowania wszystkich albo prawie wszystkich „bezpieczników” praworządności. Zdemontowanie jednego „bezpiecznika" nie musi powodować, że dochodzi do zagrożenia praworządności. Komisja Europejska, przygotowując dokument o nowych ramach praworządności, postarała się to zdefiniować przez pryzmat pełnego katalogu zasad, są to: legalność, co oznacza przejrzysty, odpowiedzialny, demokratyczny i pluralistyczny proces uchwalania prawa, pewność prawa, zakaz arbitralności działań władz wykonawczych, niezależny bezstronny sąd, skuteczna kontrola sądowa, w tym kontrola poszanowania praw podstawowych, oraz równość wobec prawa. Należy też zwrócić uwagę na dwa bardzo istotne przepisy — art. 19 ust. 1 TUE stanowiący, że państwa członkowskie ustanawiają środki niezbędne dla zapewnienia skutecznej ochrony prawnej w dziedzinach objętych prawem Unii, oraz art. 47 KPP UE nawiązujący do art. 6 EKPC. Artykuły te mają zarówno wymiar proceduralny, jak i materialny i rodzą pytanie, w jakim stopniu Komisja Europejska i Trybunał Sprawiedliwości są kompetentne do badania tego, co dzieje się w tym zakresie w państwach członkowskich, a także jak prawo Unii wpływa na postępowanie sądów krajowych, jeśli chodzi o wymiar unijny. Wymiar ten objawia się w bardzo interesujących orzeczeniach dotyczących tak zwanej wspólnej przestrzeni sądowej, w ramach której funkcjonują dwie niezwykle istotne kwestie: zasada wzajemnego zaufania sądów i systemów, z pytaniem do czego jest to zaufanie, czy jedynie do technicznej sprawności orzecznictwa i tego, czy proces toczy się szybciej czy wolniej, czy chodzi tutaj o wzajemne zaufanie sądów. Co do tego drugiego wariantu znaczyłby on, że sąd w innym państwie powinien wiedzieć, czy gdy pojawia się na przykład europejski nakaz aresztowania pochodzący z Polski, to nie ma żadnego problemu z niezawisłością i prawem do rzetelnego procesu. Jest to właśnie zaufanie do tego, że podzielamy wspólne wartości, a dopiero $\mathrm{z}$ tego wynika zasada wzajemnej uznawalności. Rodzi to ogromną odpowiedzialność po stronie sądów rozstrzygających danego państwa członkowskiego - dotyczy to zarówno sądów wzywających, jak i sądów wykonujących, a także odnosi się do tego, jak się ma zachować sąd lub sędzia orzekający w kraju, w którym istnieje zagrożenie. Jest też kwestia współpracy z Trybunałem Sprawiedliwości, która odgrywa coraz istotniejszą rolę. Pojawia się więc znowu pytanie o granice tego wzajemnego zaufania, skoro następuje bardzo interesujący rozwój orzecznictwa, dotyczący i dotykający naszego systemu prawnego.

Moderator w tym momencie poprosił o zabranie głosu przez współpanelistów. Głos zabrała Dr Agnieszka Frąckowiak-Adamska, która odnotowała i podkreśliła, że orzecznictwo będące przedmiotem konkursu zasługuje na uznanie również $\mathrm{z}$ tego powodu, że odwoływanie się do orzecznictwa TSUE w sprawach cywilnych wciąż jest niecodzienne $\mathrm{w}$ orzecznictwie sądowym. Z przeprowadzanych 
przez panelistkę badań orzecznictwa w ramach grantów UE wynika, że z przeanalizowanych 128 orzeczeń sądów wydanych w zakresie współpracy w sprawach cywilnych tylko w 31 powołano się w ogóle na orzecznictwo Trybunału, a jedynie w 4\% z owych 128 sądy odwoływały się do preambuły rozporządzenia. Panelistka wyraziła zapatrywanie, że nagradzane orzecznictwo na zasadzie „kuli śniegowej" będzie stanowić wzór do naśladowania dla innych sądów i sędziów w RP. Następnie zwróciła uwagę, że na dziś zasada zaufania jest najbardziej zarysowana w ramach Przestrzeni Wolności, Bezpieczeństwa i Sprawiedliwości (PWBiS). Ta ostatnia właśnie wydaje się najważniejszym obszarem, w którym ta zasada działa, przy czym bez wzajemnego zaufania nie byłoby oczywiście całej Unii jako takiej. PWBiS obejmuje sprawy wizowe, imigracji, azylu, współpracę sądów w sprawach cywilnych, a także współpracę w sprawach karnych, które, według panelistki, można rozważać na trzech płaszczyznach. Pierwsza to oczywiście płaszczyzna psychologiczna, to jest - jak to się rozumie potocznie - czy państwo jako sędziowie mają zaufanie do sędziów z Rumunii, Niemiec czy Portugalii.

W ramach innego projektu przeprowadzanego z ośrodkiem w Utrechcie (Holandia) badania dotyczące ENA pokazały, że w Polsce jest bardzo wysoki poziom zaufania do sędziów z innych krajów, co nie pokrywa się z poziomem zaufania innych krajów do krajów naszej części Europy. Bez wytyczania bliższego podziału geograficznego, lecz biorąc pod uwagę orzecznictwo ETPC, można wskazać, że koresponduje to z naruszeniami pewnych praw człowieka i z nimi wiąże się brak zaufania. Nasi sędziowie, stosując na przykład ENA, wykazują wysoki poziom zaufania i raczej nie kwestionują i nie badają tego, czy, przekazując osoby do innego państwa, narażają ją na naruszenie praw podstawowych. Tymczasem sędziowie z Wielkiej Brytanii czy Holandii nagminnie zadają pytania sędziom i adwokatom, powołują biegłych, aby zbadać, czy niejako u nas orzeczenie będzie wykonanie. Dotyczy to Polski, lecz także innych krajów, względem których były prowadzone badania - Rumunii, Węgier. Widać, że w Europie nie ma jednolitej odpowiedzi na pytanie, czy istnieje zaufanie na płaszczyźnie psychologicznej z różnych względów, na przykład historycznych, to zaufanie jest zróżnicowane. Można również mówić o wzajemnym zaufaniu w kontekście wzajemnego uznawania orzeczeń i poziom tego zaufania jest różny w zależności od danego aktu prawnego Unii ustanawiającego procedurę w danych sprawach. Są akty, które w ogóle nie przewidują odmowy uznawania orzeczeń, są także akty prawa Unii, które przewidują bardzo szerokie przesłanki odmowy uznania. Zasada zaufania rozumiana jako wzajemne uznawanie nie jest definiowana jednolicie, ale zależy od aktu prawnego. Poziom tego zaufania na tej drugiej płaszczyźnie wciąż wzrasta w porównaniu ze stanem prawnym sprzed dwudziestu albo dziesięciu lat, pojawiają się bowiem kolejne akty prawne, które wymagają coraz wyższego poziomu zaufania. Wzajemne uznawanie wiąże się z dojrzałością tego systemu, lecz powstaje też pytanie o jego granice w tym systemie. Świadczy to, że system działa, zaczynamy bowiem zastanawiać się, jakie są jego granice. Po trze- 
cie, wzajemne zaufanie jawi się też jako ogólna zasada prawa Unii Europejskiej, a przynajmniej tak została określona w opinii rzecznika generalnego (dalej: RG) Yves'a Bota, porównywalnie do innych zasad ogólnych prawa Unii, czyli skutku bezpośredniego i pierwszeństwa. Zatem, jak się wydaje, jest to kandydat na trzecią z podstawowych zasad ogólnych prawa unijnego i rola tej zasady jest teraz szczególnie widoczna. Jeszcze 10 lat temu mało komu przyszłoby do głowy, aby kwestionować mechanizmy unijne oparte na zasadzie wzajemnego zaufania czy to w sprawach azylowych, karnych, czy cywilnych — właściwie nikt tego nie robił. W 2012 roku zastanawiałem się jeszcze, jakie w ogóle mogłyby być podstawy odmowy ze względu na naruszenie zaufania. Teraz widzimy, że tych podstaw jest dużo. Zaczęło się od spraw azylowych, od sprawy N.S. ${ }^{9}$, w której Trybunał po raz pierwszy powiedział, że jeśli państwo nie ufa innemu państwu w kwestii przestrzegania praw podstawowych, to nie może stosować mechanizmu unijnego, mimo że zasadniczo mechanizm nakazywał sądowi przekazanie danej osoby. Chodziło o przekazanie do Grecji i niezapewnienie właściwych warunków osobom ubiegającym się o azyl. Jeśli państwo nie ma zaufania, to nie powinno tej osoby przekazać, mimo że zasadniczo mechanizmy unijne nakazują takie przekazanie. $\mathrm{Z}$ drugiej strony, TS w sprawie Zarraga ${ }^{10}$ uznał, że przekazanie dziecka nakazane rozporządzeniem musi być wykonane, nawet jeśli sąd ustalił, że nie wysłuchano dziecka. Natomiast później w słynnej sprawie $2 / 13^{11}$ uznano, że zasada ta jako zasada ogólna ma materialną treść, która sprowadza się do wymagania od państw członkowskich, aby uznawały, że inne państwa przestrzegają praw Unii, w tym praw podstawowych, czyli treścią zasady wzajemnego zaufania jako zasady ogólnej jest domniemanie, że inne państwa przestrzegają praw podstawowych unijnych i tylko w wyjątkowych wypadkach może ona być ograniczona. Trybunał orzekał tutaj ,z zastrzeżeniem wyjątkowych okoliczności", a wobec tego uznał na pewno, że ta zasada nie może być absolutna, że zaufanie nie może być absolutne, ale jego niestosowanie musi być ograniczone do wyjątkowych okoliczności. Później w sprawach karnych problem ten powrócił, gdy sądy niemieckie zastanawiały się, czy przekazać osoby podejrzane i oskarżone do Rumunii i na Węgry. Sądy niemieckie nabrały podejrzeń, że te osoby mogą być tam nieludzko traktowane, ze względu na to że ETPC wydał wiele wyroków dotyczących złych warunków w więzieniach tych państw. Co do Węgier, było to 450 spraw przed ETPCz, a Trybunał wydał wyrok pilotażowy, że te osoby są poddawane nieludzkiemu traktowaniu (art. 3 EKPC). Sąd niemiecki zadał wtedy pytanie, czy należy przekazywać takie osoby. Zdaniem Yves’a Bota

9 Wyrok Trybunału (wielka izba) z dnia 21 grudnia 2011 roku, sprawy połączone N.S. (C-411/10) przeciwko Secretary of State for the Home Department i M. E. i inni (C-493/10) przeciwko Refugee Applications Commissioner i Minister for Justice, Equality and Law Reform, EU:C:2011:865.

10 Wyrok Trybunału z dnia 22 grudnia 2010 roku, sprawa C-491/10 PPU Joseba Andoni Aguirre Zarraga przeciwko Simone Pelz, EU:C:2010:828.

11 Powyżej, EU:C:2014:2454. 
należało je bezwzględnie przekazać, mimo że owo przekazanie mogłoby naruszyć art. 3 EKPC. Po wydaniu opinii rzecznik wskazał, że gdy sądy krajowe zaczną się zastanawiać nad ochroną praw podstawowych w ten sposób, to zniszczy to efektywność systemu ENA, który jego zdaniem dotychczas bardzo dobrze działał. Po owej wypowiedzi RG ukazał się list otwarty organizacji chroniących prawa podstawowe „Opinia RG Yves'a Bota — zagrożenie dla praworządności w Europie". Zaapelowano, aby TS nie szedł za niechlubnym przykładem rzecznika, a jeśli tak by się stało, to aby KE niezwłocznie wykorzystała inicjatywę prawodawczą i wniosła o uregulowanie podstaw odmowy uznania. Niedługo później TS wydał wyrok ${ }^{12}$, w którym stwierdził, że art. 3 EKPC nie podlega ograniczeniom i jeśli sąd będzie miał dane na to, że istnieje niebezpieczeństwo systemowe, to powinien zbadać w indywidualnej sprawie, czy dotyczą takiej osoby. Jeśli dotyczą, to nie powinien jej przekazywać. Można uznać, że było to zwycięstwo praw podstawowych nad wzajemnym zaufaniem. Mamy więc do czynienia z zasadą ogólną, która wciąż się kształtuje, a o jej granicach nadal dyskutuje.

Następnie moderator przekazał głos Dr. Maciejowi Taborowskiemu, odnotowując, że Trybunał poszedł jeszcze dalej w najnowszym orzecznictwie. Panelista wskazał, że TS znów wszedł w etap wydawania wyroków istotnych dla Unii jako unii prawa i przypomniał, że pojęcie rządów prawa zostało wprowadzone przez Trybunał w 1986 roku $^{13}$ i obecnie znajduje się w art. 2 TUE. Obecnie zaś w obliczu problemów z praworządnością w systemach niektórych państw członkowskich TS powoli zaczyna udzielać odpowiedzi, jak będzie reagował na takie problemy państw członkowskich. Są to dwa wyroki - w sprawie sędziów portugalskich $^{14}$ oraz w sprawie $A c h m e a^{15}$ dotyczący umów BIT. Świadczy to, że niezależnie od roli Komisji jako strażniczki Traktatów, sprawa będzie rozstrzygnięta przez TS we współpracy z sądami krajowymi. Dwa orzeczenia są wyraźnym sygnałem dla sądów krajowych, ich wzmocnieniem w walce o skuteczność prawa Unii. W sprawie Achmea na kanwie umów o ochronie inwestycji TS wykluczył, aby mógł istnieć sąd polubowny ustanowiony przez państwa członkowskie, wyjęty ze struktury systemu prawa UE i niezachowujący jego autonomii. Drugie zaś orzeczenie w sprawie sędziów portugalskich — trzeba widzieć je razem — jest wzmocnieniem sądów krajowych w walce o wartości i skuteczność prawa unijnego. To orzeczenie dotyczyło kwestii tymczasowego obniżenia wynagrodzenia sędziów w Portugalii, ma ono znaczenie fundamentalne i jest już wymieniane

12 Wyrok Trybunału z dnia 5 kwietnia 2016 roku, sprawy połączone C-404/15 i C-659/15 PPU Pál Aranyosi i Robert Căldăraru przeciwko Generalstaatsanwaltschaft Bremen, EU:C:2016:198.

13 Por. wyrok Trybunału z dnia 23 kwietnia 1986 roku, sprawa 294/83 Parti écologiste „Les Verts" przeciwko Parlamentowi Europejskiemu, EU:C:1986:166.

${ }^{14}$ Wyrok Trybunału z dnia 27 lutego 2018 roku, sprawa C-64/16 Associação Sindical dos Juizes Portugueses przeciwko Tribunal de Contas, EU:C:2018:117.

15 Wyrok Trybunału z dnia 6 marca 2018 roku, sprawa C-284/16 Slowakische Republik przeciwko Achmea BV, EU:C:2018:158. 
,jednym tchem” z orzeczeniami Van Gend czy Costa. Z uwagi na to, że po raz pierwszy Trybunał odniósł się do art. 19 TUE, o którym była mowa, czyli zasad skutecznej ochrony sądowej w dziedzinach objętych prawem Unii, i zinterpretował go w ten sposób, że nie tak jak dotychczas w sprawie musi koniecznie wystąpić element unijny, który dopiero uzasadniał zastosowanie, na przykład Karty praw podstawowych i standardów unijnych dotyczących niezawisłości sędziów i niezależności sądów, tylko odszedł od takiego ścisłego rozumienia zastosowania tych standardów. Powiedział, że wystarczy, że sąd krajowy potencjalnie może interpretować albo stosować prawo unijne - jeżeli tak, to jest on chroniony przez standardy unijne, chroniona jest jego niezawisłość oraz inne elementy, które znajdziemy w systemie prawa unijnego. Ten wyrok ma kluczowe znaczenie dla sądów krajowych, w szczególności tych, które mogą znaleźć się w takim systemie. Przesuwa on bardzo daleko granice pomiędzy sprawą, która nie ma elementu unijnego i sprawą unijną. Wcześniej walczono i szukano dyrektywy, swobody — tak jak przy tych nazwiskach - czy przepisów o obywatelstwie unijnym. W tym wypadku wystarczy natomiast tylko potencjalne stosowanie prawa Unii. Wyrok ten daje zielone światło Komisji, lecz ona metaforycznie jeszcze na nich stoi. Jeśli chodzi o system polski, to wiadomo, że w marcu wniesiono skargę KE przeciwko Polsce w przedmiocie dyskryminacji ze względu na płeć przy przechodzeniu sędziów w stan spoczynku. Skarga ta opiera się właśnie na takim tradycyjnym rozumieniu elementu unijnego. Był tam ten drobny element dotyczący praworządności, aspektu niezawisłości sędziego — dotyczył regulacji, że Minister Sprawiedliwości na podstawie uznaniowych kryteriów decyduje, czy sędzia może pełnić dalej funkcję, czy też nie. Portugalski wyrok takie podejście zasadniczo zmienia, bowiem w sprawie, która dotyczyłaby między innymi niezawisłości sędziów, wystarcza, że sąd potencjalnie może stosować prawo Unii, jednak nie jest konieczna konkretna norma, na przykład dyrektywy. Jest to istotne przesunięcie akcentu dla sądów krajowych. Sprawa ta oczywiście może mieć znaczenie dla sprawy Cel$m e r^{16}$, czyli tak zwanej sprawy irlandzkiej. Rozprawa była przewidziana w trybie pilnym 1 czerwca 2018 roku. W dotychczasowym orzecznictwie TSUE przygotowywał się na tego typu sprawę, czego przykład stanowi sprawa portugalska. W tej ostatniej TS wyraźnie połączył skuteczną ochronę sądową z wymogami państwa prawa i art. 2 TUE. Grunt pod ewentualne orzeczenie jest już więc przygotowany. Wcześniej również nie zdarzyło się, że powoływany był art. 2 TUE, a zasady, które obecnie są podpinane pod ten artykuł — zasada skutecznej ochrony sądowej, trójpodział władzy — funkcjonują już od dawna. Od paru lat owe zasady są podpinane jednak pod art. 2 TUE, a więc jest tworzony pewien ,pparasol” z zasad stanowiących elementy państwa prawa. Istnieje możliwość, że w pewnym mo-

16 Por. w oryginale orzeczenia irlandzkiego High Court w sprawie Minister v Celmer: http://www. courts.ie/Judgments.nsf/0/578DD3A9A33247A38025824F0057E747; http:/www.courts.ie/Judgments. nsf/0/FD843302847F2E228025825D00457F19; http://www.courts.ie/Judgments.nsf/0/66CEB4EB1500E22F8025825D0045CA98 (dostęp: 23.05.2018). 
mencie naruszenie art. 2 TUE będzie mogło być uznane za samoistne naruszenie, gdy norma ta będzie już skonkretyzowana. Na razie takiej sprawy nie było i obecnie art. 2 TUE działa jako coś, co pomaga w wykładni zasad, które stanowią jego element, w tym zasady skutecznej ochrony sądowej.

W tym miejscu moderator zwrócił uwagę zebranych na fakt, że istotny element sprawy portugalskiej stanowi, że jej przedmiotem jest coś, czego prawo UE nigdy nie regulowało i regulować nie będzie - wynagrodzenia sędziów krajowych. W ten sposób można było zająć stanowisko, że nawet jeśli wpływałoby to na niezawisłość sędziowską, to Trybunał nie powinien się tym zajmować. Paradoksem jest, że w sprawie portugalskiej było to stanowisko KE, uznawanej za „proeuropejską". Okazuje się jednak, że nie ma żadnego problemu i TS powinien być kompetentny do rozpoznania sprawy. Kłóci się to z poglądami zaprezentowanymi w tak zwanej białej księdze Rady Ministrów RP ${ }^{17}$, w której wskazano, że instytucje Unii powinny być powściągliwe oraz że istnieć ma ,zasada powściągliwości" w prawie Unii.

Panelista po ponownym udzieleniu mu głosu odnotował, że Trybunał oderwał stosowanie KPP UE i stosowanie art. 19 TUE. KPP UE i jej art. 47 mogą dalej mieć zastosowanie w zakresie stosowania prawa Unii, natomiast art. 19 TUE został potraktowany jako dający element unijny, gdzie to stosowanie jest jedynie potencjalne i Karta sama z siebie nie byłaby stosowana. Natomiast stosowanie art. 19 TUE otwiera również stosowanie Karty i jej pełnego wachlarza. Niezwykle interesująca będzie odpowiedź Trybunału w sprawie Celmer, w której orzeczenie w sprawie Aranyosi zostało zaadaptowane przez sąd irlandzki do systemowego problemu z praworządnością w Polsce. To, co robi sąd irlandzki, to cytowanie wniosku Komisji o zastosowanie art. 7 TUE i opinii Komisji Weneckiej dotyczących polskiego porządku prawnego i dochodzenia do wniosku na okoliczność tego, co jest w tych dokumentach - wszystkie elementy dyskusji od kilku lat, TK, KRS, sądy. W istocie sąd irlandzki sam przesądził o tym, że Polska naruszyła art. 2 TUE. Pytanie, które sąd ten zadał, dotyczy konsekwencji tego naruszenia. Czy więc system wypracowany na podstawie orzeczenia Aranyosi może mieć zastosowanie do sytuacji z orzeczenia Celmer? W zasadzie sędzia irlandzka jest przekonana, że osoba wysłana do polskiego systemu prawnego nie będzie miała szansy na rzetelny proces. Pyta więc, czy system orzeczenia Aranyosi ma zastosowanie, a także, jaki test prawny stosować. Aranyosi zakłada dwustopniowy test — po pierwsze, ogólne informacje o zagrożeniu systemowym w państwie członkowskim, co uchyla domniemanie wzajemnego zaufania. Sprawdza się tutaj, czy istnieje konkretne niebezpieczeństwo względem danej osoby. Później następuje kontakt z danym państwem członkowskim, żeby dowiedzieć się o miejscu osadzenia. Po przeanalizowaniu orzecznictwa holenderskiego w stosunku do Węgier i Rumunii jawi się wniosek, że automatycznie sądowi, który wystawił nakaz, za-

17 https://www.premier.gov.pl/files/files/biala_ksiega_pl_full.pdf (dostęp: 23.05.2018). 
daje się pytanie, gdzie będzie osadzona dana osoba. W zależności od odpowiedzi, czy ośrodek spełnia standardy, czy nie albo gdy odpowiedź jest niepełna bądź niczego niegwarantująca, to te sądy wydają lub nie wydają tej osoby. Trybunał zezwolił więc na zróżnicowanie między państwami członkowskimi - dopuszcza, że to sąd krajowy, sędzia krajowy będzie decydować na podstawie swojego przekonania, czy jest w stanie pogodzić się z decyzją, że wyśle do tego systemu osobę oskarżoną. System Aranyosi zakłada też neutralność Trybunału Sprawiedliwości, który działa jako „pas transmisyjny” i nie zajmuje stanowiska. Mówi on, że sąd krajowy ma pewne dostępne informacje - orzecznictwo strasburskie, opinie na przykład sądów krajowych pochodzących z tego systemu, opinie stowarzyszeń prawniczych międzynarodowych. Są to informacje, którym można ufać, a ponadto należy dokładnie dowiedzieć się o aktualnym stanie rzeczy w danym państwie. $\mathrm{Na}$ tej podstawie uchyla się domniemanie. Potem TS mówi, że sąd krajowy ma sprawdzić, czy jest realne ryzyko, które musi być sprawdzone na podstawie dostępnych informacji, a następnie ma wyciągnąć konsekwencje. Te konsekwencje są nie do końca jasne, bowiem w sprawie Aranyosi TS wstrzelił się nieco między przepisy, mówiąc, że należy wstrzymać procedurę ENA - nie powiedział, że należy odmówić, tylko „zobaczyć, co się będzie działo”. Granicą zaś dla tego, „co się będzie działo", są zasady ogólne — długość, to znaczy, że nie można kogoś przetrzymywać w nieskończoność. Granica wstrzymania gdzieś jest, ale niewyjaśniona. Istotne jest to, że TS nie musi zająć stanowiska odnośnie do tego, co się dzieje w państwie członkowskim.

W tym momencie głos ponownie zabrała dr Frąckowiak-Adamska, wskazując, że wprawdzie w sprawach praw podstawowych Trybunał nie zajmował stanowiska, to jednak wydaje się, że takie stanowisko będzie musiał zająć w sprawie praworządności. Jeśli TS odbiłby piłeczkę do sędziego irlandzkiego, to byłoby to odbicie odpowiedzialności. Właściwie przy systemowych naruszeniach pierwszym aktorem, który powinien zająć stanowisko, jest Rada Europejska - państwa, które tworzą organizację. Jeśli uznamy i weźmiemy pod uwagę opinie Komisji Weneckiej, uchwały sądów, na przykład Sądu Najwyższego, uchwały rad wydziałów, to wydaje się, że 95\% uczestników uważa, że dochodzi do naruszenia niezawisłości sędziowskiej. Są głosy, że nic się nie dzieje i są to głosy rządu. Jednak znaczna liczba uczestników debaty jest za istnieniem naruszenia. Skoro jest to sprawa tak poważnej wagi, to powinna się tym zająć również Rada, lecz Rada — jak na razie — nie zajęła się tym. W drugiej sytuacji jest to też Komisja, jako strażniczka Traktatów, która powinna zainicjować procedurę z art. 7 TUE albo przynajmniej korzystać ze skargi, o której mowa w art. 258 TFUE za konkretne, poszczególne naruszenia. Jednak Komisja również niejako wycofała się. Ostatecznie ów ,gorący ziemniak” trafia do TS, który będzie musiał taką systemową sprawę rozstrzygnąć. Chciałbym dodać, że w decyzji ramowej w sprawie ENA jest w preambule zaznaczone, że mechanizm z art. 7 TUE oznacza zawieszenie mechanizmu ENA. Jeśli przestrzeń sądowa jest oparta na zaufaniu, to jest 
to zaufanie do systemów prawnych oraz do organów sądowych i są to dwie różne rzeczy. Cała integracja unijna jest możliwa dzięki temu, że państwa mają podobne systemy prawne, jeśli chodzi o podstawy i wartości, a jednocześnie jeszcze kontrolowane z punktu widzenia EKPC. Oczywiście te systemy są różne - czy chodzi o sprawy cywilne, czy karne - jednak opierają się na tych samych wartościach. Zaufanie do systemów w ogóle pozwala na stworzenie tej przestrzeni, ale drugi bardzo ważny element stanowi zaufanie do sądów. To zaufanie jest wyrażane tym, że sądy w innym państwie nie kontrolują merytorycznie decyzji sądów $\mathrm{z}$ innego państwa, one je tylko wykonują albo uznają, natomiast nie badają, czy decyzja jest merytorycznie dobra.

W tym miejscu moderator zwrócił uwagę na wartość tej konkluzji dla całego systemu PWBiS jako takiego, a nie tylko dla ENA, i jakie to będzie miało konsekwencje także dla funkcjonowania rynku wewnętrznego i dla spraw rodzinnych. Za jednym orzeczeniem i za ENA stoi więc coś, co jest podstawą funkcjonowania Unii nie w potocznym odbiorze.

Panelistka, zgadzając się z tym poglądem, wskazała, że chodzi o całe prawo cywilne i karne, a przy swobodzie przemieszczania się osób i naszych obywatelach za granicą tych orzeczeń jest bardzo dużo. Jest to więc zaufanie do systemów prawnych i organów sądowych. W sytuacji gdy brakuje wzajemnego zaufania, biorąc pod uwagę na przykład uchwały naszego Sądu Najwyższego, jak można wymagać, aby inne sądy bezkrytycznie przyjmowały orzeczenia z naszego kraju? Problemem jest, jaką Trybunał wybierze odpowiedź — czy powie, że należy systemowo zawiesić stosowanie tych mechanizmów? To byłoby najradyklaniejsze, a stanowiłoby też decyzję, która zastąpiłaby te brakujące decyzje Rady z art. 7 TUE i Komisji, która nawet nie pozwała Polski. Tak naprawdę bezczynność instytucji naprawia sąd irlandzki w ramach kontroli horyzontalnej, co dobitnie pokazuje rolę sędziów.

Panelistka wskazała też, że sprawność systemu może być przesłanką braku zaufania. Czasem może być tak, że system jest niewydolny — tak jak z niemożliwością załatwienia wszystkich spraw uchodźców w Grecji. Grecja nie chciała tych uchodźców źle traktować, jednak ich liczba przekroczyła możliwości organizacyjne tego państwa. Nie zakładamy, że Grecy zrobili to specjalnie. Zakładamy też że państwa - Polska, Węgry — nie chcą specjalnie umieszczać skazańców w przepełnionych więzieniach i traktować ich nieludzko. Czasem jednak państwa są niewydolne organizacyjne. Są więc trzy kwestie: zaufanie do systemu prawnego, zaufanie do organów sądowych oraz zaufanie do sprawności państwa. Jeśli państwo specjalnie odejdzie od wartości, na których opiera się UE, to tego zaufania też nie powinno być. Jeśli sądy nie będą niezawisłe — trudno mówić o zaufaniu, jeśli państwo nie jest w stanie wypełniać swoich obowiązków — to dlaczego inne państwa miałyby mu ufać?

Doktor Taborowski w uzupełnieniu wypowiedzi przedmówczyni dodał, że należy rozważyć jeszcze scenariusz co byłoby, gdyby TS nie zajął się sprawą pra- 
worządności. Wprawdzie paneliści rozważyli pięć albo sześć scenariuszy, ale są trzy główne ścieżki. Pierwsza jest taka, że TS powie, że system Aranyosi dotyczący praw podstawowych nie ma w ogóle zastosowania do kwestii praworządności, a tak naprawdę w tym wypadku trzeba będzie znaleźć jakieś inne rozwiązanie. Skrajną odpowiedzią, niekorzystną z punktu widzenia polskiego systemu prawnego, byłoby, że Trybunał zająłby się przyczynami pytania, co daje mu możliwość wypowiedzenia się na temat polskiego systemu prawnego, podobnie jak w sprawie łódzkiej ${ }^{18}$. Jest też druga możliwość, ,środkowy pas transmisyjny”, że Trybunał wskaże kryteria, które powinny być wzięte pod uwagę przez sąd krajowy. Niebezpieczeństwo polega na tym, że sąd krajowy jest zobowiązany stosować standardy prawa krajowego oraz EKPC, na co sąd irlandzki zwraca uwagę. Odpowiedź Trybunału, która uniemożliwiłaby stosowanie pewnego rodzaju ochrony przez ten sąd, mogłaby sprawić, że sądy te „pójdą w swoim kierunku”, aby chronić swoje systemy przed systemem, który jest przez nie uważany za „problemowy". Dobry przykład takiego orzeczenia stanowi orzeczenie niemieckiego Bundesverfassungsgericht (Federalnego Trybunału Konstytucyjnego) z grudnia 2016 roku $^{19}$ dotyczące obywatela amerykańskiego, który miał być wydany na podstawie ENA z Niemiec do Włoch. Okazało się, że nie był poinformowany o procesie włoskim, w którym został skazany. Sąd niemiecki powiedział, że tego typu naruszenie wchodzi w zakres tożsamości konstytucyjnej, która „nie podlega negocjowaniu”. Jest więc ryzyko, że sąd krajowy pójdzie „własną drogą” i wyjdzie spod kontroli TS, a wtedy UE będzie miała większy problem, jeśli chodzi o jednolite stosowanie instrumentów UE.

Moderator odnotował, tytułem jednolitego stosowania, że ewentualne powoływanie się na tożsamość konstytucyjną i art. 4 ust. 2 TUE, aby uzasadnić autonomię krajową, może mieć odwrotny skutek: inne państwa zaczną się powoływać na art. 4 ust. 2 TUE, aby uzasadnić izolowanie tego państwa w systemie i egzekwowanie praworządności. Jednocześnie lektura pytania irlandzkiego wywołuje ubolewanie nad krytyczną oceną systemu polskiego. Tytułem niezależności sądu można również wskazać, że istotne znaczenie mają warunki i przesłanki orzecznictwa oraz checklist Komisji Weneckiej: autonomia sędziego, niepodleganie hierarchii służbowej, niepodporządkowanie nakazom i wytycznym, brak krytycznego stanowiska wobec wyrokowania, ochrona przed ingerencją i naciskami — zwłaszcza politycznymi, zagrażającymi niezależności osądów — oraz bardzo ważny element: wpływ władzy wykonawczej. Można tutaj wrócić do wątku „irlandzcy sędziowie Sądu Najwyższego są powoływani przez władzę wykonawczą”. Otóż działanie władzy wykonawczej jest dopuszczalne tylko wtedy, gdy istnieje taka

18 Zapewne panelista miał na myśli wyrok Trybunału z dnia 13 października 2016 r., sprawa C-303/15 Naczelnik Urzędu Celnego I w Ł. przeciwko G.M. i M.S., EU:C:2016:771.

19 Takie orzeczenie nie zostało opublikowane. Por. http://www.bundesverfassungsgericht. de/SiteGlobals/Forms/Suche/EN/Entscheidungensuche_Formular.html?nn=5403310\&facettedYe$\operatorname{ar}=2016+2017 \&$ facettedMonth=12\&language_=en (dostęp 23.05.2018). 
kultura polityczna i długa tradycja mogąca zapewnić oderwanie rozstrzygnięć od kryteriów politycznych. Konkluzją tego aspektu może być przypomnienie sprawy Baka przeciwko Węrom rozpoznanej przez ETPC ${ }^{20}$. Pojawia się tam wątpliwość, jak należy chronić niezawisłość sędziowską. Moderator przypomniał stan faktyczny sprawy Baka przeciwko Wegrom i wyraził pogląd, że mimo interwencji ETPC zmiany systemowe na Węgrzech były nieodwracalne w obliczu zniesienia węgierskiego Sądu Najwyższego i faktycznym uniemożliwieniu zatrudnienia przez sędziego Bakę.

W zakończeniu dr Frąckowiak-Adamska wyraziła pogląd, że jeśli odczytanie sprawy portugalskiej jest prawidłowe w ten sposób, że nastąpiło oderwanie wymogu utrzymywania niezależnych organów sędziowskich od jakiegokolwiek innego obowiązku unijnego, to w każdej sprawie można zadać pytanie prejudycjalne dotyczące zgodności z prawem Unii, w tym co do „reform” polskiego sądownictwa.

Panelista wskazał, że wprawdzie jego zdaniem musiałoby mieć miejsce potencjalne stosowanie prawa UE, natomiast standard podlegałby zasadzie pierwszeństwa i w tym zakresie może uchylać środki krajowe. Panelistka dodała, że może też mieć miejsce orzeczenie zabezpieczenia i wstrzymanie środków krajowych.

Dyskusję zakończyło podsumowanie Profesora Zbigniewa Lasocika i krótkie wystąpienie Profesora Andrzeja Rzeplińskiego, który wskazał, że miejsce Polaków jest w Europie Zachodniej, a prawo międzynarodowe i art. 45 Konstytucji RP wymaga od każdego sędziego, aby wykazywał nieskazitelność charakteru i moral integrity.

20 Por. https://hudoc.echr.coe.int/app/conversion/pdf/?library=ECHR\&id=002-9473\&filename= 002-9473.pdf\&TID=thkbhnilzk (dostęp: 23.05.2018). 